\title{
Some virulence genes of Escherichia coli isolated from cloacal swabs of healthy Alagoas Curassows (Pauxi mitu) in Brazil ${ }^{1}$
}

\author{
André A.B. Saidenberg ${ }^{2}$, Luciana Allegretti², Claudete C.S. Astolfi-Ferreira², \\ Antônio J.P. Ferreira² ${ }^{2}$ Marcelo A. Almeida ${ }^{3}$ and Tânia F. Raso ${ }^{2 *}$
}

\begin{abstract}
Saidenberg A.A.B., Allegretti L., Astolfi-Ferreira C.C.S., Ferreira A.J.P., Almeida M.A. \& Raso T.F. 2013. Some virulence genes of Escherichia coli isolated from cloacal swabs of healthy Alagoas Curassows (Pauxi mitu) in Brazil. Pesquisa Veterinária Brasileira 33(4):523-527. Faculdade de Medicina Veterinária e Zootecnia (FMVZ), Universidade de São Paulo, Av. Dr. Orlando Marques de Paiva 87, São Paulo, SP 05508-270, Brazil. E-mail: tfraso@usp.br

Birds of the Cracidae family (curassows, guans, and chachalacas) are endemic of the Neotropics and 50 species are currently classified. Brazil has 22 species, seven of which are considered threatened. The Alagoas Curassow (Pauxi mitu) species is considered extinct in the wild; but about 120 birds are alive in captivity. Conservation of this species depends entirely on correct management. Health reports of both wildlife and captive curassows are rare. In this study the presence of Escherichia coli was evaluated in 23 healthy Alagoas Curassows from two private breeding centres. E. coli was isolated from cloacal swabs, and the presence of genes encoding cytotoxic necrotising factor 1 (cnf1), alpha-haemolysin (hly), aerobactin (iuc), serum resistance (iss) and the following adhesions: S fimbriae ( $s f a$ ), pili associated with pyelonephritis ( $\mathrm{pap}$ ) and temperature-sensitive haemagglutinin ( $t s h$ ) were investigated. E. coli was isolated from $78.3 \%(18 / 23)$ of the birds, and the percentage of curassows colonized by E. coli was similar between the two facilities. From the 22 E. coli isolates, 15 (68.2\%) were positive for at least one virulence factor by PCR, and the most frequently found gene was iss (50\%). No curassows had clinical signs of disease. Nevertheless, the presence of some E. coli strains may be a concern to the wildlife in captivity. Additional health surveillance studies are essential to guarantee successful conservation programmes for threatened cracids in Brazil.
\end{abstract}

INDEX TERMS: Cracidae, Alagoas Curassow, Pauxi mitu, Escherichia coli, virulence genes.

RESUMO.- [Alguns genes de virulência de Escherichia coli isoladas de mutuns-do-nordeste (Pauxi mitu) sadios no Brasil.] Aves da família Cracidae (mutuns, jacutingas e aracuãs) são endêmicas da região Neotropical com 50 espécies atualmente classificadas. 0 Brasil possui 22 espécies nesta família e sete delas são consideradas ameaçadas de extinção. 0 mutum-do-nordeste (Pauxi mitu) é considerado extinto na natureza, no entanto, aproximadamente 120 indivíduos são mantidos em cativeiro. A conservação desta espécie depende inteiramente de um manejo

\footnotetext{
${ }^{1}$ Received on July 2, 2012.

Accepted for publication on February 7, 2013.

${ }^{2}$ Departamento de Patologia, Faculdade de Medicina Veterinária e Zootecnia (FMVZ), Universidade de São Paulo (USP), Av. Dr. Orlando Marques de Paiva 87, São Paulo, SP 05508-270, Brazil. *Corresponding author: tfraso@usp.br

${ }^{3}$ Instituto Chico Mendes de Conservação da Biodiversidade (ICMBio), EQSW 103/104, Bloco C, Setor Sudoeste, Brasilia, DF 70670-350, Brazil.
}

correto. Informações sobre o status sanitário de mutuns são raras, tanto em vida livre quanto em cativeiro. Neste estudo a presença de Escherichia coli foi avaliada em 23 mutuns-do-nordeste sadios de dois criatórios particulares. E. coli foi isolada a partir de suabes cloacais, em seguida, foi avaliada a presença de genes que codificam fator citotóxico necrotizante 1 (cnf1), alfa-hemolisina (hly), produção de aerobactina (iuc) e resistência sérica (iss) e genes que codificam os seguintes fatores de virulência: fímbria $\mathrm{S}(s f a)$, pili associado à pielonefrite ( $p a p$ ) e hemaglutinina termosensível (tsh). E. coli foi isolada de 78,3\% (18/23) das aves e o percentual de mutuns positivos para $E$. coli foi semelhante entre as duas criações. De 22 isolados de E. coli, 15 (68,2\%) foram positivos para pelo menos um fator de virulência pela PCR e o gene mais frequente foi o iss (50\%). Nenhuma ave apresentava sinal clínico de doença, no entanto, a presença de determinadas cepas de E. coli pode representar 
uma preocupação em relação às aves silvestres mantidas em cativeiro. Estudos adicionais de monitoria do status sanitário do plantel são essenciais para garantir o sucesso de futuros programas de conservação de cracídeos ameaçados no Brasil.

TERMOS DE INDEXAÇÃO: Cracídeos, mutum-do-nordeste, Pauxi mitu, Escherichia coli, genes de virulência.

\section{INTRODUCTION}

The Cracidae is one of the most endangered bird families in the World. Birds of the Cracidae family comprise the large Galliformes of Central and South American tropics and subtropics. They are popularly known as curassows, guans and chachalacas with 50 currently accepted species. Approximately half of the known species are highly endangered. Brazil has 22 species, and seven taxa are also considered as threatened (Brooks \& Fuller 2006). Large species of guans and curassows are frugivorous occurring mostly in mature primary forests, and particularly vulnerable to hunting and habitat fragmentation (Keane et al. 2005). The presence of such large species is considered to be a good bioindicator, which helps to determine if natural resources are being overexploited (Strahl \& Grajal 1991, Guix \& Ruiz 1997).

The Alagoas Curassow (Pauxi mitu) is of particular interest because it is considered extinct in the wild, with approximately 120 individuals surviving in captivity in two private breeding centres in Brazil (Silveira et al. 2004, Brooks \& Fuller 2006). The last forest remnants where Alagoas Curassows originally inhabited have been destroyed and replaced by sugarcane plantations to supply the demands for the production of ethanol fuel (Teixeira 1986).

Wild Galliformes are susceptible to several diseases that affect poultry, such as salmonellosis, colibacillosis, reticuloend otheliosis, chlamydiosis and mycoplasmosis (Gerlach 1994, Tocidlowski et al. 1999). Escherichia coli is one of the most commonly found infectious agents in birds and causes chronic respiratory disease, coligranuloma, colliform cellulitis, swollen-head syndrome, peritonitis, salpingitis, omphalitis, osteomyelitis, synovitis, panophthalmitis, and colisepticemia (Barnes et al. 2008).

$E$. coli is recognised as part of the normal intestinal microbiota of Galliformes, and non-pathogenic strains are classified as avian faecal E. coli (AFEC). However, some strains can cause disease and have been shown to possess virulence factors pattern, such as described as follow: adhesins ( $p a p$ and $s f a$ ), with the capacity to survive the host immune system response (iss, hly, and cnf1), iron acquisition systems (iuc), and cytotoxic effects among several other factors that assist the bacterial colonisation and invasion ( $t s h)$. Usually these strains are denominated as Extraintestinal Pathogenic E. coli (ExPEC), which harbour those genotypic profiles. ExPEC are important pathogens for animals, including, different species of birds, and for human leading to several clinical manifestations (Barnes et al. 2008). ExPEC includes avian pathogenic E. coli (APEC), neonatal meningitis associated E. coli (NMEC), uropathogenic E. coli, and septicemia-causing E. coli (Barnes et al. 2008). These strains are quite similar, regarding expression of genes and pathogenicity. The avian pathogenic E. coli (APEC) pathotype is well described as harbouring several virulence factors that are linked to pathogenicity (Dho-Moulin \& Fairbrother 1999, Ewers et al. 2005, Johnson et al. 2008, Knöbl et al. 2011).

Polymerase chain reaction (PCR) is a useful diagnostic tool with high specificity that can be employed to detect genes that are responsible for virulence factors found in APEC clinical cases. Although some studies have been published recently on the evolution, taxonomy and conservation of this family, only limited data are available about the health status of curassows. Then, the purpose of this study was to investigate the presence of $E$. coli and the virulence genes in healthy Alagoas Curassows.

\section{MATERIALS AND METHODS}

This research was conducted in two breeding centres in Southeastern Brazil. Cloacal swab samples were taken from 23 adult healthy Alagoas Curassows (Pauxi mitu). Nine birds were evaluated in facility 1 , and 14 birds were evaluated in facility 2 .

Sterile cloacal swabs samples were obtained from each curassows, stored in transport medium (Stuart, DIFCO) and maintained at $4^{\circ} \mathrm{C}$ until bacterial examination. Standard bacteriology methods were employed for isolation and identification of E. coli. Briefly, samples were incubated in brain heart infusion (BHI) broth (DIFCO) at $37^{\circ} \mathrm{C}$ for $24 \mathrm{~h}$. A loopful of the sample was streaked onto MacConkey (DIFCO) agar plates, and the plates were then incubated at $37^{\circ} \mathrm{C}$ for $24 \mathrm{~h}$. Escherichia coli colonies were biochemically characterised employing the EPM-MILI-Simmons Citrate

Table 1. PCR primers used for detection of the Escherichia coli genes and amplicon size

\begin{tabular}{|c|c|c|c|}
\hline Primer & Sequence & $\begin{array}{l}\text { Amplicon size } \\
\text { (base pairs) }\end{array}$ & Reference \\
\hline iucD & 5'-TAC CGG ATT GTC ATA TGC AGA CCG T-3' & $602 \mathrm{bp}$ & Yamamoto et al. 1995 (23) \\
\hline & 5'-AAT ATC TTC CTC CAG TCC GGA GAA G-3' & & \\
\hline cnf1 & $\begin{array}{l}\text { 5'-AAG ATG GAG TTT CCT ATG CAG GAG-3' } \\
\text { 5'-CAT TCA GAG TCC TGC CCT CAT TAT T-3' }\end{array}$ & $498 \mathrm{bp}$ & Yamamoto et al. 1995 (23) \\
\hline$s f a$ & $\begin{array}{l}\text { 5'-CTC CGG AGA ACT GGG TGC ATC TTA C-3' } \\
\text { 5'-CGG AGG AGT AAT TAC AAA CCT GGC A-3' }\end{array}$ & $410 \mathrm{bp}$ & Yamamoto et al. 1995 (23) \\
\hline papG & 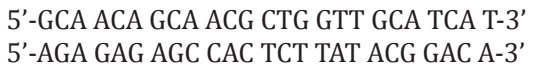 & $336 \mathrm{bp}$ & Yamamoto et al. 1995 (23) \\
\hline hlyA & $\begin{array}{l}\text { 5'-AAC AAG GAT AAG CAC TGT TCT GGC T-3' } \\
\text { 5'-ACC ATA TAA GCG GTC ATT CCC GTC A-3' }\end{array}$ & 1177 bp & Yamamoto et al. 1995 (23) \\
\hline iss & $\begin{array}{l}\text { 5'-ATC ACA TAG GAT TCT GCC G-3' } \\
\text { 5'-CAG CGG AGT ATA GAT GCC A-3' }\end{array}$ & $309 \mathrm{bp}$ & Ewers et al. 2005 (7) \\
\hline tsh & $\begin{array}{l}\text { 5'-ACT ATT CTC TGC AGG AAG TC-3' } \\
\text { 5'-CTT CCG ATG TTC TGA ACG T-3' }\end{array}$ & $824 \mathrm{bp}$ & Ewers et al. 2005 (7) \\
\hline
\end{tabular}


enterobacteriaceae identification kit (Newprov, Brazil) (Ewing 1986). The E. coli isolates were stored at $-20^{\circ} \mathrm{C}$ with $30 \%$ glycerol until PCR analysis.

Different primer sets were used for the detection of virulence factors commonly found in APEC. The primers sequences were designed to detect genes encoding $\mathrm{S}$ fimbriae $(s f a)$, pili associated with pyelonephritis ( $p a p$ ), temperature-sensitive haemagglutinin (tsh), cytotoxic necrotising factor 1 (cnf1), alpha-haemolysin (hly), aerobactin (iuc) and serum resistance (iss). The primers used and the amplicon sizes are described in Table 1. The DNA extraction was performed as described by Boom et al. (1990). Standard PCR amplification was performed as described by Yamamoto et al. (1995) (sfa, pap, iuc, hlyA, and cnf1) and Ewers et al. (2005) (iss and $t s h$ ) for APEC. Amplified products were separated by electrophoresis with a $1.5 \%$ agarose gel containing ethidium bromide $(0.5 \mu \mathrm{g} / \mathrm{ml})$ and were visualised with an ultraviolet transilluminator. DNA fragments of interest were identified using 100- and 1000-base pair molecular markers (Invitrogen).

\section{RESULTS}

Escherichia coli was isolated from 78.3\% (18/23) of the cloacal swabs, yielding 22 isolates, as shown in Table 2 . In facility 1, E. coli was isolated in $77.8 \%(7 / 9)$ of the birds, and in facility 2 , isolated in $78.6 \%(11 / 14)$ of the tested birds. Using PCR analyses, 15 (68.2\%) E. coli isolates were positive for at least one virulence factor. The most frequent virulence factor was iss (11 isolates), followed by pap (3 isolates) and iuc ( 2 isolates). In facility 1 , only the pap and iss virulence genes were detected. In facility 2, the pap, iss, iuc, tsh and hlyA genes were detected.

Association among virulence factors was found with iss/iuc (individual 08-a) and among iuc, tsh and hlyA (individual 17-b). None of the $E$. coli isolates carried the genes sfa and cnf1.

\section{Table 2. Genes encoding virulence factors detected by PCR of Escherichia coli isolates from cloacal swabs of Alagoas Curassows (Pauxi mitu)}

\begin{tabular}{|c|c|c|c|c|c|c|c|}
\hline Facility & Bird & Isolates* & pap & iss & iuc & $t s h$ & hlyA \\
\hline \multirow[t]{9}{*}{1} & 01 & $\mathrm{a}$ & + & - & - & - & - \\
\hline & & $\mathrm{b}$ & - & - & - & - & - \\
\hline & 02 & $\mathrm{a}$ & + & - & - & - & - \\
\hline & 03 & $\mathrm{a}$ & - & + & - & - & - \\
\hline & 04 & $\mathrm{a}$ & - & - & - & - & - \\
\hline & 05 & $\mathrm{a}$ & - & + & - & - & - \\
\hline & 06 & $\mathrm{a}$ & - & + & - & - & - \\
\hline & & $\mathrm{b}$ & - & + & - & - & - \\
\hline & 07 & $\mathrm{a}$ & - & - & - & - & - \\
\hline \multirow[t]{14}{*}{2} & 08 & $\mathrm{a}$ & - & + & + & - & - \\
\hline & & $\mathrm{b}$ & - & + & - & - & - \\
\hline & 09 & $\mathrm{a}$ & - & + & - & - & - \\
\hline & 10 & $\mathrm{a}$ & - & + & - & - & - \\
\hline & 11 & $\mathrm{a}$ & - & - & - & - & - \\
\hline & 12 & $\mathrm{a}$ & - & + & - & - & - \\
\hline & 13 & $\mathrm{a}$ & - & + & - & - & - \\
\hline & 14 & $\mathrm{a}$ & - & - & - & - & - \\
\hline & 15 & $\mathrm{a}$ & - & + & - & - & - \\
\hline & 16 & $\mathrm{a}$ & + & - & - & - & - \\
\hline & 17 & $a$ & - & - & - & - & - \\
\hline & & $\mathrm{b}$ & - & - & + & + & + \\
\hline & 18 & $\mathrm{a}$ & - & - & - & - & - \\
\hline & Total & 22 & $3 / 22$ & $11 / 22$ & $2 / 22$ & $1 / 22$ & $1 / 22$ \\
\hline
\end{tabular}

*All isolates were negative for genes encoding for $s f a$ and $c n f 1$.

\section{DISCUSSION}

The knowledge about infectious diseases and microbiota in Alagoas Curassows is scarce. Health surveillance surveys focusing on this species help surviving captive curassows by enhancing husbandry practices, which consequently improve population numbers and stability. Although some studies have been published involving pathogenic Escherichia coli detection in other species of birds, mainly Psittaciformes and Columbiformes (Schremmer et al. 1999, Pedersen et al. 2006, Gonçalvez et al. 2010, Knobl et al. 2011, Saindenberg et al. 2012), is still difficult to interpret the positive results found in asymptomatic curassows.

In our study it was verified that the E. coli was isolated from 78.3\% of the cloacal swabs from Alagoas curassow, $77.8 \%$ in facility 1 and $78.6 \%$ in facility 2 . Similarly, Santos et al. (2010) also obtained isolates of E. coli in $70.5 \%$ of cloacal swabs from different species of captive cracids. However, in this case this curassow specie (Pauxi mitu) was not assessed and the virulence genes of $E$. coli were not studied. Unfortunately, the Alagoas Curassows is considered extinct in the wild, only surviving in these two private breeding centers in Brazil.

In poultry, the detection of several virulence factors of $E$. coli has been associated with clinical signs of APEC. However, no virulence factors have been exclusively linked to pathogenicity (Tivendale et al. 2004). Among the E. coli virulence factors, serum resistance has been shown to have a high correlation with pathogenicity (Mellata et al. 2003). Genes such as the tsh (temperature-sensitive haemagglutinin) and iss (serum resistance) have been reported in APEC strains. The iss gene has been associated with certain strains capable to provoke sepsis by providing bacteria with resistance against the host immune bactericidal defences (Tivendale et al. 2004). In the present study, the iss gene was detected in E. coli isolated from 9 individuals (11 isolates), all of them in good health conditions. Although the detection of the iss gene alone does not correlate with virulence, turkey faecal samples from asymptomatic and clinical cases of colibacillosis have been tested by PCR. A much higher frequency of iss has been shown to be associated with $t s h$ in symptomatic birds, suggesting that these particular strains do not constitute a major part of the normal enteric microbiota of healthy turkeys (Altekruse et al. 2002). The association of these two genes was not detected in the present study. But $t$ sh gene was detected in association with iuc and hlyA genes in an E. coli isolated from one currasow. This birds was also healthy, but it should be taken into account that $t s h$ gene has been shown to play a role in mechanisms of adherence to the respiratory tract of poultry (Dozois et al. 2000). Thus, further studies with in vivo infection should be performed for a better understanding regarding virulence genes and clinical manifestation of $E$. coli infection.

Several factors such as the ability to adhere to host tissue and iron uptake activity are fundamental to the pathogenesis of this disease. Siderophores such as aerobactin (iuc gene) enable E. coli to obtain iron stores from the host. The expression of the aerobactin/iron acquisition system is 
much more frequent among APEC isolates than AFEC isolates (Dho-Moulin \& Fairbrother 1999). Moreover, the association of both iss and iuc are necessary to achieve higher levels of virulence in colibacillosis cases affecting domestic birds (Tivendale et al. 2004). In this study, the iss gene was the most frequent virulence factor found, representing 11 isolates $(73.3 \%)$, followed by 2 iuc gene $(13.3 \%)$.

Dozois et al. (2000) showed that the tsh gene is found more frequently in cases of high lethality of colibacillosis in chickens, ducks, and turkeys. However, other authors have detected a larger number of positive samples for the same gene in asymptomatic/healthy birds (Mcpeake et al. 2005). A study with faecal samples from symptomatic and asymptomatic chickens showed that the iss, tsh, and iuc genes were actually found at higher frequencies in clinical cases, although none could be classified as exclusively causing the disease, which suggests that other unknown virulence factors, together with environmental factors, may be involved in colibacillosis outbreaks (Vanderkerchove et al. 2005).

The P fimbrial adhesin (pap gene) and S fimbrial adhesin ( $s f a$ gene) genes have also been extensively described in APEC pathogenicity. The pap gene provides the capacity to binding to internal organs and protects against heterophils (Johnson 1991), and the sfa gene has been detected in poultry with omphalitis, salpingitis, chronic respiratory diseases and sepsis (Ngeleka et al. 2002, Ewers et al. 2005, Knobl et al. 2006). In the present study, the $s f a$ gene was not found in any isolate, and the pap gene was detected in three isolates. Toxins such as alpha-haemolysin (hlyA gene) and cytotoxic necrotising factor 1 (cnf1 gene) allow these bacteria to cause tissue damage, which contributes to the dissemination and release of host nutrients while impairing the immune defences. The $c n f 1$ gene was not detected in any of these curassows.

In this study, some of the tested samples from healthy curassows were positive for the pap and hlyA genes. Usually, avian pathogenic E. coli do not encoding hlyA gene (Knöbl et al. 2006), although Johnson et al. (2008) describes detection of this gene in APEC. Our results contribute to elucidating this subject. In poultry, most E. coli infections are secondary to predisposing factors related to the environment and the host itself. Nevertheless, these results may be of concern because an imbalance may occur, especially when the birds are subjected to stress factors, such as the start of breeding season, concurrent diseases, improper husbandry, and environmental changes. All of these factors may lead to a manifestation of colibacillosis, which may have serious results if a captive population of extremely endangered species is affected. Losses due to colibacillosis in poultry farms can be considerably reduced when these factors are controlled (Dho-Moulin \& Fairbrother 1999). Moreover, with good quarantine, disease-screening protocols, and husbandry procedures, most diseases may be prevented or treated in curassow species (Tocidlowski et al. 1999).

\section{CONCLUSION}

The present study showed that some virulence genes were detected in Escherichia coli isolated from Alagoas Curasso- ws without clinical signs of disease. These results may contribute for knowledge of the health status of endangered cracids, particularly those maintained in captivity. Additional studies are essential for a better understanding of these findings in this population. Furthermore, long term health surveillances should be conducted in order to guarantee the success of conservation programs and ensure the survival of such an endangered species. Unfortunately, free-living cracid populations are declining. Thus, effective conservation actions are urgently needed to ensure their survival.

Acknowledgements.- To Roberto Azeredo, Moacyr Dias, Luís Fábio Silveira and Alexandre Paulo Armando for access to the birds sampled in this study, and to ICMBio and IBAMA for the legal permits. This study was supported by Fundação de Amparo à Pesquisa do Estado de São Paulo (FAPESP).

\section{REFERENCES}

Altekruse S.F., Elvinger F., Debroy C., Pierson F.W., Eifert J.D. \& Sriranganathan N. 2002. Pathogenic and fecal Escherichia coli strains from turkeys in a commercial operation. Avian Dis. 46:562-569.

Barnes H.J., Nolan L.K. \& Vaillancourt J.P. 2008. Colibacillosis, p.691-732. In: Saif Y.M., Fadly A.M., Glisson J.R., McDougald L.R., Nolan L.K. \& Swayne D.E.(Eds), Diseases of Poultry. Blackwell Publishing, Ames, Iowa.

Boom R., Sol C.J.A., Salimans M.M.M., Jansen C.L., Werthein-Van Dillen P.M.E. \& Van der Noordaa L. 1990. Rapid and simple method for purification of nucleic acids. J. Clin. Microbiol. 28:495-503.

Brooks D.M. \& Fuller R.A. 2006. Biology and conservation of Cracids, p.915. In: Brooks D.M., Cancino L. \& Pereira S.L. (Eds), Conserving Cracids: The most Threatened Family of Birds in the Americas. $6^{\text {th }}$ ed. Miscellaneous Publications, Houston Museum of Natural Science, Houston, Texas.

Dho-Moulin M. \& Fairbrother J.M. 1999. Avian pathogenic Escherichia coli (APEC). Vet. Res. 30:299-316.

Dozois C.M., Dho-Moulin M., Bree A., Fairbrother J.M., Desautels C. \& Curtiss R. 2000. Relationship between the tsh autotransporter and pathogenicity of avian Escherichia coli and localization and analysis of the tsh genetic region. Infect. Immun. 68:4145-4154.

Ewers C., Janssen T., Kiesling S., Philipp H-C. \& Wieler L. 2005. Rapid detection of virulence-associated genes in avian pathogenic Escherichia coli by multiplex polymerase chain reaction. Avian Dis. 49:269-273.

Ewing W.H. 1986. Edwards and Ewing's Identification of Enterobacteriaceae. Elsevier Science Publishing, New York.

Gerlach H. 1994. Bacteria, p.949-983. In: Ritchie B.W., Harrison G.J. \& Harrison L.R. (Eds), Avian Medicine: Principles and application. Wingers Publishing Inc., Lake Worth, Florida.

Gonçalves G.A.M., Almeida S.M., Lima E.T. \& Andreatti Filho R.L. 2010. Detecção de Escherichia coli e Salmonella spp. em microbiota intestinal de Psittaciformes em fase de reabilitação para soltura. Braz. J. Vet. Res. Anim. Sci. 47:185-189.

Guix J.C. \& Ruiz X. 1997. Weevil larvae dispersal by guan in SE Brazil. Biotrop. 29:522-525.

Johnson J.R. 1991. Virulence factors in Escherichia coli urinary tract infection. Clin. Microbiol. Rev. 4:80-128.

Johnson T.J., Wannemuehler Y., Doetkott C., Johnson S.J., Rosenberger S.C. \& Nolan L.K. 2008. Identification of minimal predictors of avian pathogenic Escherichia coli virulence for use as a rapid diagnostic tool. J. Clin. Microbiol. 46:3987-3996.

Keane A., Brooke M.L. \& McGowan P.J.K. 2005. Correlates of extinction risk and hunting pressure in gamebirds (Galliformes). Biol. Conservation 126:216-233.

Knöbl T., Gomes T.A.T., Vieira M.A.M., Bottino J.A. \& Ferreira A.J.P. 2006. Occurrence of adhesin-encoding operons in Escherichia coli isolated from 
breeders with salpingitis and chicks with omphalitis. Braz. J. Microbiol. 37:134-137.

Knöbl T., Saidenberg A.B.S., Moreno A.M., Gomes T.A.T., Vieira M.A.M., Leite D.S., Blanco J.E. \& Ferrreira A.J.P. 2011. Serogroups and virulence genes of Escherichia coli isolated from psittacine birds. Pesq. Vet. Bras. 31:916-921.

Mellata M., Dho-Moulin M., Dozois C.M., Curtiss R., Brown P.K., Arne P., Bree A., Desautles C. \& Fairbrother J.M. 2003. Role of virulence factors in resistance of avian pathogenic Escherichia coli to serum and in pathogenicity. Infect. Immun. 71:536-540.

McPeake S.J.W., Smyth J.A. \& Ball H.J. 2005. Characterization of avian pathogenic Escherichia coli (APEC) associated with colisepticaemia compared to faecal isolates from healthy birds. Vet. Microbiol. 110:245-253.

Ngeleka M., Brereton L., Brown G. \& Fairbrother J.M. 2002. Pathotypes of avian Escherichia coli as related to tsh-, pap-, pil-, and iuc-DNA sequences, and antibiotic sensitivity of isolates from internal tissues and the cloacae of broilers. Avian Dis. 46:143-152.

Pedersen K., Clark L., Andelt W.F. \& Salman M.D. 2006. Prevalence of shiga toxin-producing Escherichia coli and Salmonella enterica in rock pigeons captured in Fort Collins, Colorado. J. Wildl. Dis. 42:46-55.

Saidenberg A.B.S., Guedes N.M.R., Seixas G.H.F., Allgayer M.C., Assis E.P. \& Benites N.R. 2012. A survey for Escherichia coli virulence factors in asymptomatic free-ranging parrots. ISRN Vet. Sci. 6p. doi: $10.5402 / 2012 / 984813$

Santos H.F., Flôres M.L., Lara V.M., Sá e Silva M., Battisti L. \& Lovato L.T. 2010. Microbiota cloacal aeróbia de cracídeos cativos no Rio Grande do
Sul e sua susceptibilidade a antimicrobianos. Pesq. Vet. Bras. 30:10771082.

Schremmer C., Lohr J.E., Wastlhuber U., Kösters J., Ravelshofer K., Steinrück H. \& Wieler L.H. 1999. Enteropathogenic Escherichia coli in Psittaciformes. Avian Pathol. 28:349-354.

Silveira L.F., Olmos F. \& Long A.J. 2004. Taxonomy, history and status of Alagoas Curassow Mitu mitu (Linnaeus, 1766), the world's most threatened cracid. Ararajuba 12:43-50.

Strahl S.D. \& Grajal A. 1991. Conservation of large avian frugivores and the management of Neotropical protected areas. Oryx 25:50-55.

Teixeira D.M. 1986. The avifauna of the north-eastern Brazilian atlantic forest: a case of mass extinction? Ibis 128:167-168.

Tivendale K.A., Allen J.L., Ginns C.A., Crabb B.S. \& Browning G.F. 2004. Association of iss and iucA, but not $t s h$, with plasmid-mediated virulence of avian pathogenic Escherichia coli. Infect. Immun. 72:6554-6560.

Tocidlowski M.E., Norton T.M. \& Young L.A. 1999. Medical Management of Curassows. Proc. Am. Assoc. Zoo Veterinarians. Columbus, Ohio, p.295298.

Vanderkerchove D., Vandemaele F., Adriaensen C., Zaleska M., Hernalsteens J.P., Baets L.D., Butaye P., Van Immerseel F., Wattiau P., Laevens H., Mast J., Goddeeris B. \& Pasmans F. 2005. Virulence associated traits in avian Escherichia coli, comparison between isolates from colibacillosisaffected and clinically healthy layer flocks. Vet. Microbiol. 108:75-87.

Yamamoto S., Terai A., Yuri K., Kurazono H., Takeda Y. \& Yoshida O. 1995. Detection of urovirulence factors in Escherichia coli by multiplex polymerase chain reaction. FEMS Immunol. Med. Microbiol. 12:85-90. 